\title{
Evaluation of Double and Triple Antibiotic Paste Removal Efficiency of Various Irrigation Protocols
}

\section{Çeşitli İrrigasyon Protokollerinin İkili ve Üçlü Antibiyotik Patlarını Uzaklaştırma Etkinliklerinin Değerlendirilmesi}

\author{
(1) Evren Sarıyılmaz ${ }^{1}$, (1) Cangül Keskin² \\ ${ }^{1}$ Ordu University Faculty of Dentistry, Department of Endodontics, Ordu, Turkey \\ ${ }^{2}$ Ondokuz Mayıs University Faculty of Dentistry, Department of Endodontics, Samsun, Turkey
}

Keywords

Double antibiotic paste, triple antibiotic paste, regenerative endodontics, irrigation, removal efficiency

\begin{abstract}
Anahtar Kelimeler
İkili antibiyotik patı, üçlü antibiyotik patı, rejenaratif endodonti, irrigasyon, uzaklaştırma etkinliği
\end{abstract}

Received/Geliş Tarihi : 20.04.2018 Accepted/Kabul Tarihi : 19.07.2018

doi:10.4274/meandros.galenos.2018.63496

Address for Correspondence/Yazışma Adresi: Evren Sarıyılmaz MD,

Ordu University Faculty of Dentistry, Department of Endodontics, Ordu, Turkey E-mail : evrensariyilmaz@yahoo.com

ORCID ID: orcid.org/0000-0003-1711-7056

(C) Meandros Medical and Dental Journal, Published by Galenos Publishing House.

This is article distributed under the terms of the Creative Commons Attribution NonCommercial 4.0 International Licence (CC BY-NC 4.0).

\begin{abstract}
Objective: Aim of this study was to compare the double (DAP) and triple (TAP) antibiotic paste removal efficiency of conventional syringe irrigation (CSI), EndoActivator (EA), passive ultrasonic irrigation (PUI) and XP-endo finisher (XPF) from simulated immature root canals.

Materials and Methods: A total of 180 extracted mandibular canine roots were used. The apical $2 \mathrm{~mm}$ of the roots were removed, and Unicore drills were penetrated through the apical to the coronal direction approximately $1 \mathrm{~mm}$ to simulate an immature apex. Canals were prepared up to size 40 by using the Mtwo system. Roots were split longitudinally and then temporarily reassembled. The samples were randomly divided into 2 main groups as DAP and TAP. Five specimens for each main group were kept as negative control group. Then the pastes were placed with lentulo spiral. After 1 week five specimens for each main group were kept as positive control group. Then the remaining specimens in DAP and TAP groups were further assigned to 4 subgroups according to the removal technique (group 1: CSI; group 2: EA; group 3: PUI, group 4: XPF). The root halves were examined under a stereomicroscope at 10x magnification. Kruskal-Wallis $\mathrm{H}$ and Mann-Whitney $\mathrm{U}$ tests were used for statistical analyses.

Results: TAP and DAP were more effectively removed by XPF and PUI compared to $\mathrm{CSI}$ and EA $(\mathrm{p}<0.05)$. XPF and PUI DAP/TAP removal effectiveness was statistically similar ( $p>0.05)$. Moreover, CSI and EA showed similar effectiveness for both paste groups ( $p>0.05$ ). Regarding the type of antibiotic paste, no significant difference between TAP and DAP was found ( $p>0.05$ ).

Conclusion: The tested irrigation systems could not completely remove either TAP or DAP. The use of PUI or the XPF was more effective compared to the use of the $\mathrm{EA}$ and CSI.
\end{abstract}

Öz

Amaç: Bu çalışmanın amacı konvansiyonel şırınga irrigasyonu (KŞi), EndoActivator (EA), pasif ultrasonik irrigasyon (PUi), ve XP-endo finisher (XPF) ile ikili (DAP) ve üçlü (TAP) antibiyotik patlarının uzaklaştırılabilme etkinliğinin karşılaştırılması amaçlanmaktır.

Gereç ve Yöntemler: Toplam 180 adet çekilmiş mandibular kanin diş kullanılmıştır. Köklerin apikal 2 mm kısmı uzaklaştırılmıştır ve unicore frezler ile apikalden koronal 
yöne doğru yaklışık $1 \mathrm{~mm}$ ilerlenerek immature apeks simule edilmiştir. Kanallar Mtwo sistemiyle 40 numara genişliğine kadar prepare edilmiştir. Kökler longitudinal olarak ikiye ayrıldı ve sonrasında geçici olarak yeniden birleştirildi. Örnekler rastgele DAP ve TAP olarak iki ana gruba ayrıldı. Her ana grup için beşer numune negatif kontrol grubu olarak ayrıldı. Sonrasında lentulo ile patlar yerleştirildi. Bir hafta sonra her ana grup için beşer numune pozitif kontrol grubu olarak ayrıldı. Sonrasında DAP ve TAP gruplarındaki kalan numuneler uzaklaştırma yöntemine göre dörder alt gruba ayrıldı (grup 1: KŞi; grup 2: EA; grup 3: PUi, grup 4: XPF). Kök yarıları 10X büyütmede stereo mikroskop ile incelendi. Kruskal-Wallis H ve Mann-Whitney U testleri istatiksel analizlerde kullanıldı.

Bulgular: XPF ve PUI, KŞi ve EA'ya kıyasla daha etkin olarak TAP ve DAP uzaklaştırmıştır $(p<0,05)$. XPF ve PUI DAP/TAP uzaklaştırabilme etkinliği istatistiksel olarak benzerdi $(p>0,05)$. Dahası, KSi ve EA de her iki antibiyotik patı için benzer etkinlik göstermiştir $(p>0,05)$. Antibiyotik patı tiplerine bakıldığında ise TAP ve DAP arasında anlamlı farklılık bulunamamıştır $(p>0,05)$.

Sonuç: Test edilen irrigasyon sistemlerinin hiçbirisi TAP yada DAP'yi tamamen uzaklaştıramamıştır. PUI veya XPF kullanımı EA ve KSi ile kıyaslandığında daha etkilidir.

\section{Introduction}

Regenerative endodontics aims to restore necrotic immature teeth to a healthy state and to promote further root development and reinforcement of dentinal walls by the deposition of hard tissue. The success of regenerative endodontic treatment depends on the triad of pulp tissue engineering, which consists of infection control, use of biomaterials, and use of stem cells (1). Infection control is an indispensable step in endodontic regeneration to resolve periodontitis and to prevent persistent pathologic inflammation signals, which interfere with differentiation and maturation of the apical papilla cells and prevent root maturation (1). Disinfection of root canals in regenerative endodontics primarily depends on chemical debridement with minimal or no mechanical instrumentation (2). However, the polymicrobial nature of root canal infection necessitates the use of antibiotic combinations to achieve effective disinfection of root canal systems (3). Triple antibiotic paste (TAP), which consists of ciprofloxacin, metronidazole, and minocycline, has been proven highly effective against endodontic bacteria (4). Moreover, further studies were conducted to determine alternative medicament options for regenerative endodontics due to possible penicillin allergy (3) and/or the discoloration potential of the integrants, especially minocycline (5). Cefaclor (6), amoxicillin (7) and fosfomycin (8) were some recommended alternatives to minocycline in TAP and have been shown to be effective in eliminating bacteria in root canal systems. In addition, the clinical effectiveness of a double antibiotic paste (DAP) made from the combination of metronidazole and ciprofloxacin was also utilized (9).
The concentrations of antibiotics used locally in regenerative endodontics is 5.000 to 10.000 times greater than those in blood circulating levels. Therefore, the host cells as well as stem cells, which are essential for regenerative endodontics, have been under threat from non-selective toxicity of antibiotics (10). Ruparel et al. (11) revealed that TAP was destructive for stem cells. The stem cells in the periradicular region are crucial for endodontic regenerative treatments; Banch and Trope (12) study reported that the continued root formation and revascularization of the pulp occurred following the differentiation of these cells. Therefore, double and/or triple of any kind of antibiotic paste in the root canal must be removed to prevent possible tooth discoloration and detrimental effects on the host cells.

Various techniques are used for TAP removal from root canals; however, none of them can completely remove it from the root canal $(10,13)$. The recently introduced XP-endo finisher file (XPF) (FKG Dentaire SA, La Chaux-de-Fonds, Switzerland) is a unique instrument that promises an enhanced final cleaning, even in the irregularities of root canal systems, due to its enhanced flexibility and expansion capability up to $3 \mathrm{~mm}$ in diameter to touch to the canal walls in threedimensions (14). Previously, studies investigated the intracanal content removal effectiveness of the XPF with various irrigation systems (15-18). However, only a few studies have evaluated the efficacy of the XPF in removing TAP or DAP. One study compared the XPF with conventional syringe irrigation (CSI), laser activated irrigation, and Vibringe in removing DAP from artificial grooves, whereas another recent study compared XPF with passive ultrasonic irrigation (PUI) in the removal of TAP from immature roots (17). According to our literature research, there is no study that compares TAP and DAP removal efficiency of the 
XPF with the EndoActivator (EA). Therefore, the aim of this study was to investigate the efficacy of the use of XPF, PUI, EA, and CSI in the removal of TAP and DAP from simulated immature root canals. The null hypotheses were that paste removal was not affected by the technique or antibiotic ingredients.

\section{Materials and Methods}

This study was performed at both Ordu University and Ondokuz Mayıs University. The Ondokuz Mayıs University Clinical Researches Ethical Committee board approved the study protocol (OMU KAEK 2016/403). This study was performed in accordance with the World Medical Association Declaration of Helsinki and written informed consent was obtained from all participants. A total of 180 freshly extracted human mandibular canine teeth were selected. Teeth, which had immature apices, any kind of resorption, previous endodontic treatment, cracks or fractures, were excluded. The presence of single patent root canals was confirmed by using radiographs taken from the mesiodistal and buccolingual aspects. Samples were stored at $100 \%$ humidity and $37{ }^{\circ} \mathrm{C}$ till the experiments were conducted. Two $\mathrm{mm}$ of apical region the roots were removed and size 4 green 1.5 $\mathrm{mm}$ diameter Unicore drills (Ultradent Products, Inc., South Jordan, UT, USA) were penetrated approximately one $\mathrm{mm}$ through the apical to the coronal direction to simulate an immature apex. The crowns of the teeth were partially removed to standardize working lengths as $16 \mathrm{~mm}$ using a sterile diamond burs under water-cooling and then the endodontic access was prepared. Afterwards, a \#10 K-file (Dentsply Maillefer, Ballaigues, Switzerland) was used to extirpate the pulp. Mtwo NiTi rotary file system (VDW, Munich, Germany) up to \#40 (40.04) file was used to prepare root canals under 1.5\% sodium hypochlorite $(\mathrm{NaOCl})$ irrigation. A 30-g sidevented irrigation needle (NaviTip; Ultradent, South Jordan, UT, USA) was used for irrigant delivery. After the chemomechanical root canal preparation, the root canals were irrigated using distilled water $(2 \mathrm{~mL})$, $17 \%$ ethylenediaminetetraacetic acid (EDTA), $(2.5 \mathrm{~mL})$ and finally distilled water $(2 \mathrm{~mL})$, respectively. Then, \#40 paper points were used to dry the root canals of the specimens.

A test apparatus that described in a previous study by Topçuoğlu et al. (19), was used for this study. The roots were placed in silicone impression material (Zetaplus; Zhermack, Rovigo, Italy) and then placed in $1.5 \mathrm{~mL}$ Eppendorf tubes. Afterwards, waited until the silicone was completely set. Next, the teeth were removed from the test apparatus and longitudinal grooves on the lingual and buccal surfaces of the roots were prepared. Subsequently, the roots were split into halves using a hammer and chisel. Debris from the root halves was removed using a toothbrush under running tap water. A small amount of cyanoacrylate glue (Scotch Super Glue Gel; 3M, St. Paul, MN, USA) was used to temporarily brought the root halves together to have adequate structural darability to the effect of DAP/TAP placement and removal procedures and transportation till the microscopic investigations. Subsequently, the samples were remounted into the impression in the Eppendorf tubes. The samples were divided into two major groups: the DAP and TAP groups.

Ten specimens were randomly chosen as negative controls for the DAP and TAP groups $(n=5)$ and were not subjected to further procedures. In the TAP group, equal portions of metronidazole (Sanofi, İstanbul, Turkey), ciprofloxacin (BioFarma, İstanbul, Turkey), and cefaclor (Basel, İstanbul, Turkey) powders were mixed (1:1:1); whereas metronidazole and ciprofloxacin were mixed in a 1:1 ratio for DAP. Then distilled water was mixed with antibiotic powder mixtures (liquid/powder ratio of 1:3) (20) and then this freshly prepared TAP and DAP was placed into each root canal with a lentulo spiral according to its working length and packed by using size 0 Buchanan hand plugger (SybronEndo, Scafati, Italy). Then the specimen was removed from the tube and the presence of excess antibiotic paste was confirmed at the immature root tip to ensure that the root canals were completely filled with the antibiotic paste. The extruded part of the paste was removed by using moist gauge and the specimens were remounted into the tubes. Cotton pellets were placed on the TAP and DAP, and than some temporary sealing material (Cavit G; 3M ESPE, Seefeld, Germany) was used to seal the access cavities. The apical openings were also sealed with temporary sealing material to prevent the pastes from dissolving due to humidity during the storage period. Afterwards, all the samples were stored at 37 ${ }^{\circ} \mathrm{C}$ at $100 \%$ humidity for one month. 
At the end of one month, 10 specimens from the TAP and DAP groups were kept as positive controls $(n=5)$, and so any removal procedure did not applied to them. A \#15 K-file was introduced into the root canal to loosen the antibiotic paste to create a pathway for the syringe needle. The samples in the DAP and TAP groups were divided into four subgroups as described below $(n=20)$.

Group 1 (CSI): Five $\mathrm{mL}$ of $1.5 \% \mathrm{NaOCl}$ was used to irrigate the root canals for one minute followed by a one minute irrigation with five $\mathrm{mL}$ of $17 \%$ EDTA using a 30-g side-vented irrigation needle (NaviTip; Ultradent) that placed one $\mathrm{mm}$ short of the WL.

Group 2 (EA): Five $\mathrm{mL}$ of $1.5 \% \mathrm{NaOCl}$ was used to irrigate the root canals and then a polymer tip (25/04) that mounted on a EA device was introduced into the canal two mm short of the WL and it was run at 10.000 cpm (cycles per minute) with vertical movements of an amplitude of two $\mathrm{mm}$ for one minute. Next, the canals were irrigated with five $\mathrm{mL}$ of $17 \%$ EDTA, which was activated using the EA device for one minute. One polymer tip was used for one sample and then discarded.

Group 3 (PUI): Five $\mathrm{mL}$ of $1.5 \% \mathrm{NaOCl}$ was used to irrigate the root canals and then a 15.02 ultrasonic tip [ESI instrument, piezoelectric ultrasonic unit (EMS), Le Sentier, Switzerland], which mounted on a EMS with the power setting at 6 , was placed one $\mathrm{mm}$ short of the $\mathrm{WL}$ and activated for one minute to ultrasonically activate the irrigant. The root canals were irrigated again using five $\mathrm{mL}$ of $17 \%$ EDTA and then the same procedure that described above was applied for the following 1 minute. Each of the ultrasonic tips was discarded after three usages.

Group 4 (XPF): The XPF was mounted on an endodontic motor (VDW Gold, Munich, Germany) and then it was cooled down using Chloraethyl (Dr. Georg Henning $\mathrm{GmbH}$, Walldorf, Germany). Afterwards the plastic tube, which was covered the XPF, was removed. The XPF was inserted to the root canal that flushed with five $\mathrm{mL}$ of $1.5 \% \mathrm{NaOCl}$ and the XPF was run according to manufacturer's recommendations, which was $800 \mathrm{rpm}$ speed and $1 \mathrm{~N} . \mathrm{cm}$ torque values, for one minute with vertical strokes of 7-8 $\mathrm{mm}$ to the full WL. Afterwards, the canals were irrigated again using five $\mathrm{mL}$ of $17 \%$ EDTA and the XPF was activated for another one minute. One XPF per sample was used and then discarded.
Finally, each samples was flushed using five $\mathrm{mL}$ of distilled water. The total irrigant volume of $15 \mathrm{~mL}(5 \mathrm{~mL}$ of $\mathrm{NaOCl}$, EDTA and distilled water) was used for each sample in all groups. One experienced endodontist performed all these described procedures. The temporary glued root halves were separated into two again and each of these halves was investigated under 10x magnification using a stereomicroscope, and digital images of them were taken. Two experienced endodontists, who were blinded to the groups, were scored the digital images using a classification that previously described by van der Sluis et al. (21):

Score 0: No DAP/TAP residuals were observed in the root canal.

Score 1: DAP/TAP residuals was observed in less than half of the root canal.

Score 2: DAP/TAP residuals was observed in more than half of the root canal.

Score 3: The root canal was completely filled with DAP/TAP residuals.

Shapiro-Wilk test showed that the data were not normally distributed using IBM SPSS Statistics 21.0 software (IBM, Armonk, NY, USA) $(p<0.05)$. The Kruskal-Wallis $H$ and Dunn's tests were used to analyse the differences among TAP and DAP removal scores. The level of significance was set at $95 \%$.

\section{Results}

The result of the Kappa test revealed that the interexaminer agreement was $97.1 \%$. The positive control samples verified that no TAP or DAP was removed from the root canals during the transportation and disassembly processes. The scores of the positive control group and the negative control group were significantly different from all tested groups $(p<0.05)$. Table 1 and Table 2 detail the distribution of scores of all groups. The Kruskal-Wallis $\mathrm{H}$ test showed that there were statistically significant differences in the TAP and DAP removal scores among the tested groups $(p<0.05)$. The PUI and XPF removed significantly more TAP and DAP than CSI and the EA $(p<0.05)$. There were no statistically significant differences between the XPF and PUI in both the TAP and DAP groups ( $p>0.05)$. There were no significant differences between CSI and the EA in the TAP and DAP groups ( $p>0.05$ ). Regarding the type of the antibiotic paste, no significant difference between TAP and DAP was found $(p>0.05)$. 


\begin{tabular}{|c|c|c|c|c|c|}
\hline Group & $n(N)$ & 0 & 1 & 2 & 3 \\
\hline Negative control & $5(10)$ & $10(100 \%)$ & $0(0 \%)$ & $0(0 \%)$ & $0(0 \%)$ \\
\hline Positive control & $5(10)$ & $0(0 \%)$ & $0(0 \%)$ & $0(0 \%)$ & $10(100 \%)$ \\
\hline Group $1(\text { CSI })^{a}$ & $20(40)$ & $0(0 \%)$ & $12(30 \%)$ & 11 (27.5\%) & $17(42.5 \%)$ \\
\hline Group $2(E A)^{a}$ & $20(40)$ & $0(0 \%)$ & $20(50 \%)$ & $11(27.5 \%)$ & $9(22.5 \%)$ \\
\hline Group 3 (PUI) & $20(40)$ & 19 (47.5\%) & $18(45 \%)$ & $3(7.5 \%)$ & $0(0 \%)$ \\
\hline Group $4(\mathrm{XPF})^{\mathrm{b}}$ & $20(40)$ & 23 (57.5\%) & 15 (37.5\%) & $2(5 \%)$ & $0(0 \%)$ \\
\hline \multicolumn{6}{|c|}{$\begin{array}{l}\text { CSI: Conventional syringe irrigation, EA: Endo activator, PUI: Passive ultrasonic irrigation, XPF: XP-endo finisher file, n: Number of specimens, N: Total } \\
\text { number of the scored specimens } \\
\text { a,b: Groups that do not share the same superscript letter are significantly different }(p<0.05)\end{array}$} \\
\hline
\end{tabular}

\begin{tabular}{|c|c|c|c|c|c|}
\hline Group & $n(N)$ & 0 & 1 & 2 & 3 \\
\hline Negative control & $5(10)$ & $10(100 \%)$ & $0(0 \%)$ & $0(0 \%)$ & $0(0 \%)$ \\
\hline Positive control & $5(10)$ & $0(0 \%)$ & $0(0 \%)$ & $0(0 \%)$ & $10(100 \%)$ \\
\hline Group $1(\mathrm{CSI})^{\mathrm{a}}$ & $20(40)$ & $0(0 \%)$ & $12(30 \%)$ & $11(27.5 \%)$ & $17(42.5 \%)$ \\
\hline Group $2(E A)^{a}$ & $20(40)$ & $2(5 \%)$ & $21(52.5 \%)$ & 14 (35\%) & $3(7.5 \%)$ \\
\hline Group 3 (PUI) ${ }^{b}$ & $20(40)$ & $13(32.5 \%)$ & $26(65 \%)$ & $1(2.5 \%)$ & $0(0 \%)$ \\
\hline Group 4 (XPF) & $20(40)$ & $20(50 \%)$ & $16(40 \%)$ & $4(10 \%)$ & $0(0 \%)$ \\
\hline \multicolumn{6}{|c|}{$\begin{array}{l}\text { CSI: Conventional syringe irrigation, EA: Endo activator, PUI: Passive ultrasonic irrigation, XPF: XP-endo finisher file, } n \text { : Number of specimens, N: Total } \\
\text { number of the scored specimens } \\
\text { a,b: Groups that do not share the same superscript letter are significantly different }(p<0.05)\end{array}$} \\
\hline
\end{tabular}

\section{Discussion}

Antibiotic paste mixtures are used for the disinfection of the root canal system during regenerative endodontic procedures or as an intracanal medicament for further disinfection. However, previous studies led some concerns about their usage due to allergic reactions, bacterial resistance, tooth discoloration, decrease in root dentin microhardness, and their detrimental effects on stem cells $(3,5,11,22)$. Ruparel et al. (11) reported that any antibiotic pastes used for regenerative endodontic procedures present concentration-dependent effects on the survival of stem cells. The authors also emphasized that the survival rate of the stem cells dramatically increased when the selected antibiotic concentration was below $1 \mathrm{mg} / \mathrm{mL}$. Thus, in order to increase the survival rate of the stem cells, any antibiotic paste remnants should also be removed completely at the last session of regenerative endodontic therapy.
$\mathrm{NaOCl}$ also has concentration-dependent detrimental effects on the stem cells of the apical papilla; however, a $1.5 \%$ concentration of $\mathrm{NaOCl}$ has been shown to present minimal detrimental effects (23). Therefore, a $1.5 \% \mathrm{NaOCl}$ solution was preferred as an irrigant in this study, and it was combined with $17 \%$ EDTA. A previous study showed that combining EDTA and $\mathrm{NaOCl}$ could more effectively remove TAP than either $\mathrm{NaOCl}$ or EDTA alone, especially from the apical third of the root canal (13).

The novel XPF file was developed in order to fit to the root canal system three dimensionally, and it is suggested for intracanal paste removal by the manufacturer. The present study compared the efficacy of the use of XPF, EA, PUI, and CSI in the removal of TAP or DAP from root canals with simulated immature apices. To the authors' knowledge, there is no study comparing the novel XPF with the EA regarding TAP and DAP removal efficacy. The results of our study 


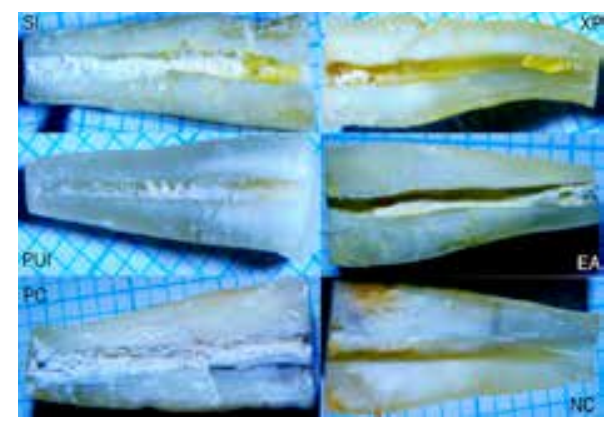

Figure 1. Representative images of the double antibiotic paste groups. Persistence of double antibiotic paste residues can be seen in all specimens

SI: Conventional syringe irrigation, PUI: Passive ultrasonic irrigation, XP: XP endo finisher; EA: EndoActivator, PC: Positive control, NC: Negative control

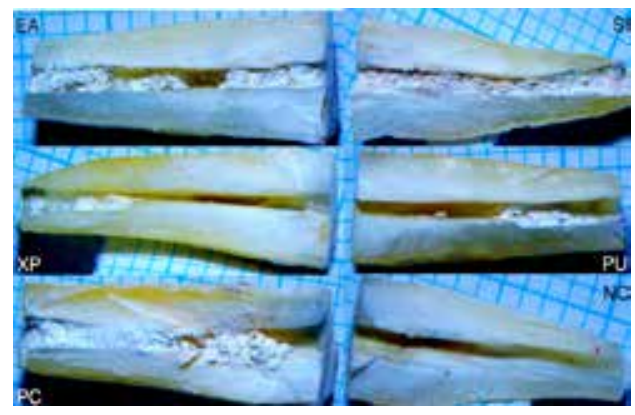

Figure 2. Representative images of the triple antibiotic paste groups. Persistence of triple antibiotic paste residues can be seen in all specimens. SI; Conventional syringe irrigation

PUI: Passive ultrasonic irrigation, XP: XP-endo finisher; $E A$ : EndoActivator, PC: Positive control, NC: Negative control, SI: Conventional syringe irrigation

revealed that the use of XPF, EA PUI, and CSI failed to completely remove DAP (Figure 1 ) and TAP (Figure 2).

Previous studies reported that no method could completely remove polyantibiotic pastes from root canal system up to date $(10,24,25)$. The findings of this study were supported the literature. Nevertheless, the use of the XPF and PUI improved TAP and DAP removal compared to needle irrigation and the use of the EA. Therefore, the first null hypothesis that there would be no difference among the various irrigation activation systems in removing TAP or DAP could be rejected.

In the present study, the TAP mixture was modified using cefaclor instead of minocycline. Minocycline, which was one of the substances of TAP, binds to calcium ions via chelation and forms an insoluble complex that has been lead to tooth discoloration (26). To overcome this problem, it was suggested to remove the minocycline from the combination or substitute minocycline with alternative antibiotics $(6,22,23)$. Cefaclor, which was reported to exhibit sufficient antimicrobial effectiveness within the canal system, has been used as an alternative to minocycline $(6,8)$. The second null hypothesis was accepted, since the presence of TAP or DAP within the root canal system did not influence the removal efficacy of the tested activation systems, which was in accordance with the findings of Arslan et al. (20).

The similarity between the efficacies of the EA and CSI is in accordance with the previous literature that evaluated the calcium hydroxide paste removal efficacy of the EA and CSI $(18,19)$. These results might be attributed to the inability of sonic activation to create a cavitation effect. However, a direct comparison could not be made among studies since Berkhoff et al. (10) reported in their quantitative analysis that it was more difficult to remove TAP than calcium hydroxide.

Previous studies have revealed the superiority of PUI over CSI in the removal of TAP or DAP from canal surfaces or irregularities $(17,19)$. The efficacy of ultrasonically activated irrigation has been determined as a result of sufficient evidence found through a systematic review. In the present study, PUI removed TAP and DAP completely in $47.5 \%$ and $32.5 \%$ of the cases, respectively. A cavitation effect resulting in a high velocity of irrigant might contribute to the removal of antibiotic pastes from root canal systems. The XPF removed TAP and DAP completely in $57.5 \%$ and $50 \%$ of the specimens, respectively. The XPF instrument is designed with an ISO apical size of 25 and a 0.00 taper. The efficacy of the XPF in removing intracanal medicaments from canal irregularities has been reported (18), and the results were similar to what was found in the present study. The manufacturer claims that this unique instrument could expand up to $6 \mathrm{~mm}$ in diameter when activated in the root canal to adapt to the canal anatomy 3-dimensionally, so it could improve the efficiency of irrigation even in the irregularities of the root canal system.

An immature root model is useful for proving the standardization of the width and length of root canal spaces. However, the limitations of this model include its lack of ability to reflect the complexity of the root canal system that involves grooves or irregularities on root canal walls and the 2-dimensional evaluation of 
remaining intracanal polyantibiotic paste remnants from the stereomicroscopic images. Within the limitations of this study, the tested irrigation systems could not completely remove either TAP or DAP from simulated immature roots. The use of the XPF and PUI were more effective when compared to the use of the EA and CSI for the removal of antibiotic root canal pastes.

\section{Acknowledgments}

This research did not receive any specific grant from funding agencies in the public, commercial, or not-for-profit sectors. The authors thank to Prof. Dr. Şevket Metin Kara and Dr. Muhammed Akif Açıkgöz for their valuable support during stereo microscopic investigations.

\section{Ethics}

Ethics Committee Approval: This study was performed at both Ordu University and Ondokuz Mayıs University. The Ondokuz Mayıs University Clinical Researches Ethical Committee board approved the study protocol (OMU KAEK 2016/403).

Informed Consent: Written informed consent was obtained from all participants.

Peer-review: Externally and internally peerreviewed.

\section{Authorship Contributions}

Concept: E.S., C.K., Design: E.S., C.K., Data Collection or Processing: E.S., C.K., Analysis or Interpretation: C.K., Literature Search: E.S., Writing: E.S.

Conflict of Interest: No conflict of interest was declared by the authors.

Financial Disclosure: The authors deny any conflicts of interest related to this study.

\section{References}

1. Cao Y, Song M, Kim E, Shon W, Chugal N, Bogen G, et al. Pulpdentin Regeneration: Current State and Future Prospects. J Dent Res 2015; 94: 1544-51.

2. Jung IY, Lee SJ, Hargreaves KM. Biologically based treatment of immature permanent teeth with pulpal necrosis: a case series. J Endod 2008; 34: 876-87.

3. Nabeel A, Prasanna N. Antiseptics and Antibiotics Used in Regenerative Endodontics. Int J Pharm and Clin Res 2013; 5: 141-4.

4. Sato I, Ando-Kurihara N, Kota K, Iwaku M, Hoshino E. Sterilization of infected root-canal dentine by topical application of a mixture of ciprofloxacin, metronidazole and minocycline in situ. Int Endod J 1996; 29: 118-24.
5. Kim JH, Kim Y, Shin SJ, Park JW, Jung IY. Tooth discoloration of immature permanent incisor associated with triple antibiotic therapy: a case report. J Endod 2010; 36: 1086-91.

6. Thibodeau B, Trope M. Pulp revascularization of a necrotic infected immature permanent tooth: case report and review of the literature. Pediatr Dent 2007; 29: 47-50.

7. Thomson A, Kahler B. Regenerative endodontics--biologicallybased treatment for immature permanent teeth: a case report and review of the literature. Aust Dent J 2010; 55: 446-52.

8. Sato $T$, Hoshino $E$, Uematsu $H$, Noda $T$. In vitro antimicrobial susceptibility to combinations of drugs on bacteria from carious and endodontic lesions of human deciduous teeth. Oral Microbiol Immunol 1993; 8: 172-6.

9. Iwaya SI, Ikawa M, Kubota M. Revascularization of an immature permanent tooth with apical periodontitis and sinus tract. Dent Traumatol 2001; 17: 185-7.

10. Berkhoff JA, Chen PB, Teixeira FB, Diogenes A. Evaluation of triple antibiotic paste removal by different irrigation procedures. J Endod 2014; 40: 1172-7.

11. Ruparel NB, Teixeira FB, Ferraz CC, Diogenes A. Direct effect of intracanal medicaments on survival of stem cells of the apical papilla. J Endod 2012; 38: 1372-5.

12. Banchs F, Trope M. Revascularization of immature permanent teeth with apical periodontitis: new treatment protocol? J Endod 2004; 30: 196-200.

13. Topçuoğlu HS, Akt A, Topçuoğlu G, Düzgün $S$, Ulusan Ö, Akpek $F$. Effectiveness of conventional syringe irrigation, vibringe, and passive ultrasonic irrigation performed with different irrigation regimes in removing triple antibiotic paste from simulated root canal irregularities. J Conserv Dent 2016; 19: 323-7.

14. FKG Swiss Endo (2016) XP-endo Finisher: $3^{\text {rd }}$ generation. http://www.fkg.ch/sites/default/files/201610_fkg_xp_endo_ finisher_brochure_v2_en_web.pdf. Accessed May 2, 2017.

15. Alves FR, Marceliano-Alves MF, Sousa JC, Silveira SB, Provenzano JC, Siqueira JF Jr. Removal of Root Canal Fillings in Curved Canals Using Either Reciprocating Single- or Rotary Multi-instrument Systems and a Supplementary Step with the XP-Endo Finisher. J Endod 2016; 42: 1114-9.

16. Bao P, Shen Y, Lin J, Haapasalo M. In Vitro Efficacy of XP-endo Finisher with 2 Different Protocols on Biofilm Removal from Apical Root Canals. J Endod 2017; 43: 321-5.

17. Gokturk H, Ozkocak I, Buyukgebiz F, Demir O. An in vitro evaluation of various irrigation techniques for the removal of double antibiotic paste from root canal surfaces. J Appl Oral Sci 2016; 24: 568-74.

18. Keskin C, Sariyilmaz E, Sariyilmaz Ö. Efficacy of XP-endo Finisher File in Removing Calcium Hydroxide from Simulated Internal Resorption Cavity. J Endod 2017; 43: 126-30.

19. Topçuoğlu HS, Düzgün S, Ceyhanlı KT, Akt A, Pala K, Kesim B. Efficacy of different irrigation techniques in the removal of calcium hydroxide from a simulated internal root resorption cavity. Int Endod J 2015; 48: 309-16.

20. Arslan H, Akcay M, Capar ID, Ertas H, Ok E, Uysal B. Efficacy of needle irrigation, EndoActivator, and photon-initiated photoacoustic streaming technique on removal of double and triple antibiotic pastes. J Endod 2014; 40: 1439-42. 
21. van der Sluis LW, Wu MK, Wesselink PR. The evaluation of removal of calcium hydroxide paste from an artificial standardized groove in the apical root canal using different irrigation methodologies. Int Endod J 2007; 40: 52-7.

22. Prather BT, Ehrlich Y, Spolnik K, Platt JA, Yassen GH. Effects of two combinations of triple antibiotic paste used in endodontic regeneration on root microhardness and chemical structure of radicular dentine. J Oral Sci 2014; 56: 245-51.

23. Diogenes A, Henry MA, Teixeira FB, Hargreaves KM. An update on clinical regenerative endodontics. Endod Topics 2013; 28: 2-23.
24. Arslan H, Capar ID, Saygili G, Uysal B, Gok T, Ertas H, et al. Efficacy of various irrigation protocols on the removal of triple antibiotic paste. Int Endod J 2014; 47: 594-9.

25. Ok E, Altunsoy M, Nur BG, Kalkan A. Effectiveness of different irrigation solutions on triple antibiotic paste removal from simulated immature root canal. Scanning 2015; 37: 409-13.

26. Tanase S, Tsuchiya H, Yao J, Ohmoto S, Takagi N, Yoshida S. Reversed-phase ion-pair chromatographic analysis of tetracycline antibiotics. Application to discolored teeth. J Chromatogr B Biomed Sci Appl 1998; 706: 279-85. 